\title{
Comparative study of trophic guilds of free living nematodes inhabiting Rosetta Estuary and Eastern Harbor, Alexandria, Egypt
}

\author{
Hanan M. Mitwally \\ University of Alexandria, Faculty of Science, Oceanography Department, \\ Alexandria, Egypt \\ Email: $\underline{\text { h_mitwally@sci.Alex.edu.eg }}$
}

\begin{abstract}
$\mathrm{T}$ rophic composition of free living nematodes within different stations at Rosetta estuary (RE) and Eastern Harbor of Alexandria ( $E H)$ was examined. Sediments at the highly dynamic RE were subjected to intense wave action and supported significantly $(P<0.05)$ lower mean nematode density $(<5$ individuals per $10 \mathrm{~cm}^{2}$ ) than sediments within the EH. Mean nematode densities and numerical trophic abundance were highest at the semi- closed basin $(p<0.05)$ that sheltered from ilydrodynamic induced disturbance. The higher nematode abundance at EH was due to availability of food sources and heterogeneous sediment, whereas the lower nematode abundance at RE was due to homogenous sand and highly dynamical process. According to Jensen's classification (1987) trophic levels were composed of four guilds at both locations (deposit feeders, epistrate feeders, scavengers and predators). Deposit feeders dominated at the two locations ( $46.5 \%$ and $37 \%$ respectively at $\mathrm{RE}$ and $\mathrm{EH}$ ) probably due to prevalence of fine and very fine sands and the high load of organic matter. Sediment characteristics and high load of organic matter appeared to be the limiting factors controlling the relative importance of nematode trophic guilds at $\mathrm{RE}$ and $\mathrm{EH}$. The Univariate (ANOVA) and multivariate (PERMANOVA) analyses indicated that total nematode abundance and its trophic guilds were distinct between locations and among dates. No significant variation among or within stations except for scavengers. The extent to which the macro-sc.:le (Km) variability was more important than micro-scale $(\mathrm{m})$ variability was tested and revealed the higher variability on larger scale than on smaller scale due to physical, hydrodynamic process as well as sediments characteristics.
\end{abstract}

Keywords: Meiofauna, deposit feeders, epistrate feeders, scavengers, predators, multivariate analyses.

\section{INTRODUCTION}

The ecology and distribution of meiofauna inhabiting estuarine and marine sediments have been investigated in variety of biotopes from intertidal (since McIntyre, 1968; Sergeeva and Gulin, 2006) and subtidal (Wieser, 1960; Moreno et al., 2006) embayment to deep sea floor (Tselepides and Lampadaiou, 2004). In contrast little is known about structure and function of meiofauna in 
general and nematodes particularly inhabiting Mediterranean Egyptian waters (Mitwally, 1999; Mitwally et al., 2004; 2005; 2007). Previous studies of nematodes in Egyptian waters have focused on taxonomy (Micoletzky, 1922; 1924a; Gerlach, 1963; 1964). The former investigated the nematode along Suez Gulf and canal and recorded two species and the latter studied the Egyptian coast of Red Sea and recorded eight new species. However, no information exists on the population structure and trophic composition of nematodes within Rosetta estuary and Eastern harbor. In the present paper quantitative and qualitative distribution of nematodes at the $\mathrm{RE}$ and $\mathrm{EH}$ is considered.

Identification of trophic groups depends on morphology of buccal cavity. Many studies dealt with the oral structures and yielded different classification schemes and all of them agreed that the buccal cavity exhibits a great variety of form reflecting a great range in feeding strategies among marine nematodes (Wieser, 1953; 1960; Perkin, 1958; Wieser and kanwisher, 1961; Platt and Warwick, 1983; Jensen, 1986; 1987; Moens and Vincx, 1997).

Rosetta estuary is one of the most important areas for trade, agriculture and fishing activities in the north western coast of the Nile Delta. However, Rosetta is highly dynamic estuary (Inman et al., 1976; Quelennec and Manohar, 1977; Inman and Jenkins, 1984; Ahmed, 2002; Abo Zed and Shereet, 2005). Rosetta promontory on the western coast of the Nile Delta among the delta coastline has been subjected to the worst severe erosion. (UNESCO/UNDP, 1978; Frihy et al., 1991; Fanos et al., 1995). Mitwally et al. (2007a) gave detailed study of meiofauna distribution at two stretches of Rosetta estuary. They recorded eight taxa at $\mathrm{RE}$ and the ranking of nematodes was the second.

On the other hand, various studies were done in eastern harbor (EH) since 1957, indicating a temporally unsteady environment due to hydrological and climatic conditions together with the input of municipal waste water and exchange with open sea. The marine environment of the E.H. suffered from receiving considerable amount of waste effluents (mainly raw sewage) since 1976. The amoui.t of this discharge has increased six times since 1985 (Aboul Kassim, 1987; Said and Maiza, 1987; Zaghloul, 1988; Zaghloul and Halim, 1992; Labib, 1994; Nessim, 1994). These effluents have led to a considerable increase in the level of the nutrients and heavy metals in the area, compared with their outside counterparts in the neritic water of the Mediterranean (El Sayed and El Sayed, 1980; El Nady, 1981). In many sites, the surface sediment has turned to anoxic environment leading to disappearance of most of its benthic fauna and flora. Jammo (2004) concluded that anoxic bed sediment phenomenon in the Eastern zone of the E.H. was found to exist during two seasons (summer and autumn) and an apparent temporal movement of anoxic surface sediments with time towards the Harbor outside direction was noticed. Mitwally and Awads (2005) investigated the meiofauna distribution in relation to biotic and abiotic factors at the harbor and recorded nematodes as the dominant taxon. Mitwally (2007) used nematodes to copepods ratio to evaluate the pollution at the EH. 
She found that Eastern Harbor is in good shape and most sites were recovered from organic pollution. Sediments at the Eastern Harbor tended to self remediation with time.

The present work aimed to give detailed account of nematode abundance at Rosetta estuary and eastern Harbor. These two highly different ecosystems ( $\mathrm{RE}$ and $\mathrm{EH}$ ) provided an additional opportunity to examine the structure of nematode trophic guilds as potentially affected by large scale chronic disturbance.

\section{Study Area}

\section{MATERIALS AND METHODS}

A through description of Rosetta estuary and Eastern harbor is given by Mitwally et al. (2007a), Mitwally and Awads (2005) and Mitwally (2007).

At Rosetta estuary, samples were taken from five stations, one station at the Rosetta mouth and four stations at the western and eastern sides (two for each). Stations 2 and 5 were representing the eroded areas whereas, sts 3 and 4 were taken from accretion areas (Fig. 1). The chosen sites were at beach (zero depth). Rosetta estuary is characterized by the prevalence of fine and very fine sand in addition to the average ratio of organic matter; $3.11 \%$ (El Shanwany, 2004).

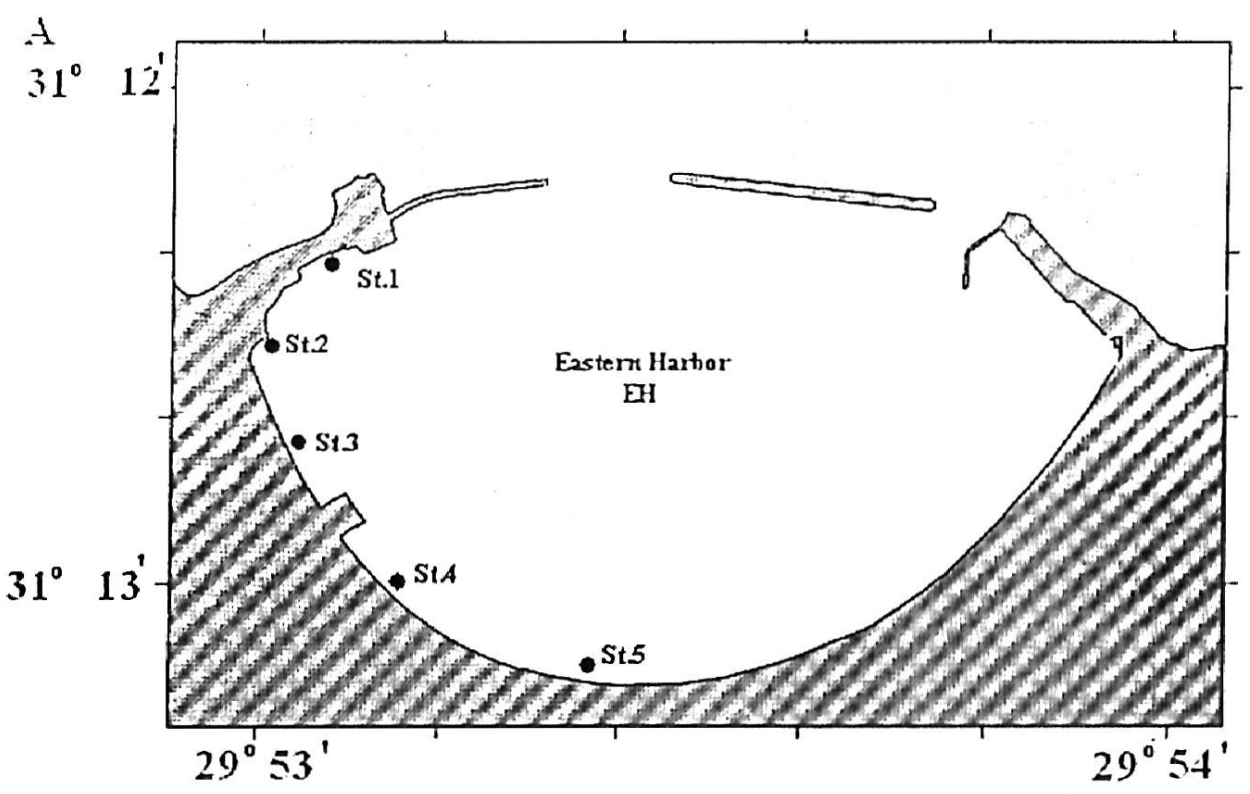

Fig.1A: Eastern Harbor map including five sampled stations distributed along the shore.

At the Eastern Harbor, five stations were chosen from the peripheral side of the semicircular shallow basin (Fig.1). Mean grain size ranged from very coarse sand to very fine silt (Al-Dughiem, 2005; Bader El Din, 2007). The 
average ratio of O.M was 1.99\% (Bader El Din, 2007). Duplicate samples were taken with syringe barrels with the needle and base cut off (length $=11 \mathrm{~cm}$. surface area $=4.9 \mathrm{~cm}^{2}$ ) at each station. Samples were taken seasonally from April 2000 to August 2001.

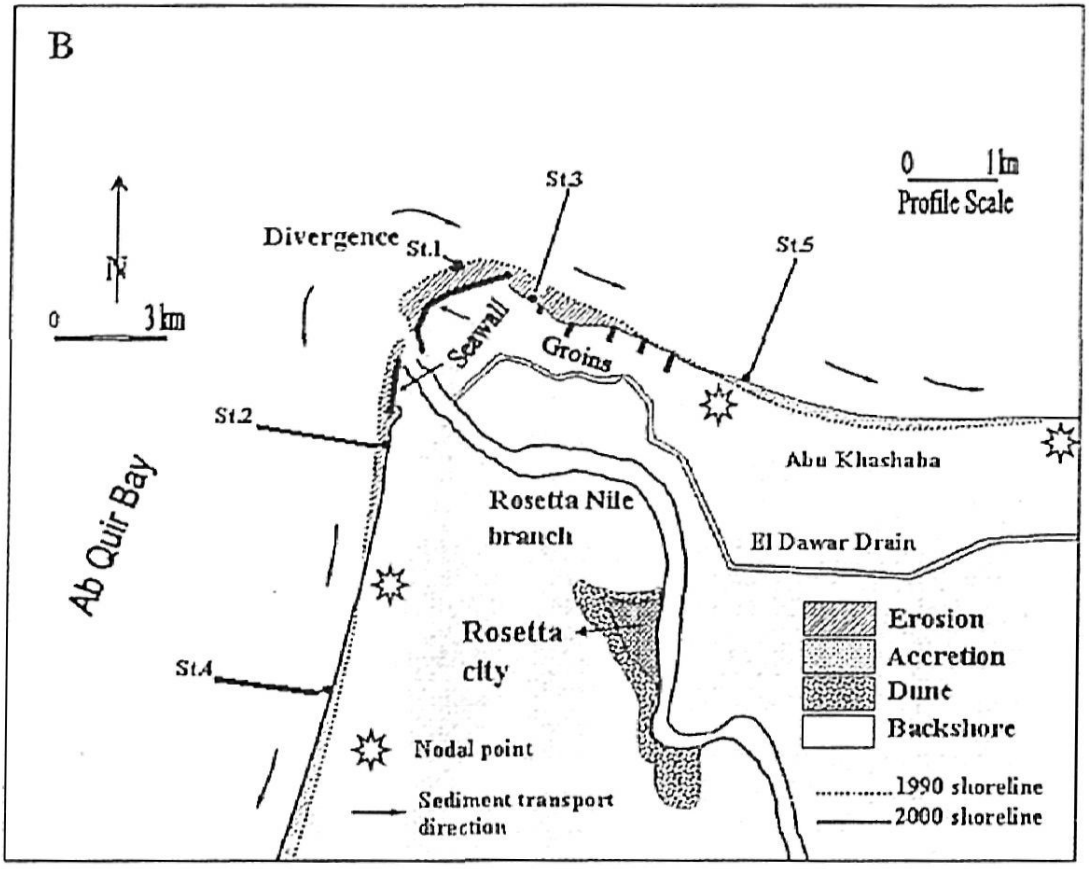

Fig.1B: Rosetta Estuary at the northwestern coast of Nile Delta including five sampled stations. St. 2 and St.5 represented the eroded areas. St.3 and St.4 were sampled from the accretion areas.

Because the aim of the current work is to investigate nematode abundance and its trophic guilds, there was no need to anesthetize samples with $\mathrm{MgCl}_{2}$.

In laboratory, samples were stained with Rose Bengal dye (for 24 hours), washed and decanted on $63 \mu \mathrm{m}$ sieves several times to extract meiofauna from sediment (Huys et al., 1998; Mitwally, 1999). All nematode specimens were sorted, counted and expressed as individuals per $10 \mathrm{~cm}^{2}$. The first 200 nematode specimens (or all nematodes when abundance was less than 60 individuals per $10 \mathrm{~cm}^{2}$ ) were picked out at random and mounted in glycerol on slides for buccal cavity examination. Nematode was assigned to trophic groups according to Jensen (1987).

Spatial patterns of total number of nematodes, total number of deposit and epistarte feeders as well as scavengers and predator's abundance were examined by 3-way analysis of variance (ANOVA), where locations multiplied 
by dates by stations (locations $\times$ dates $x$ stations). This analysis was done using SYSTAT software (1998). Three way ANOVA was performed on $4^{\text {th }}$ squared transformed data of total nematodes and their trophic guilds to reveal significant variation between locations, over dates, among and within stations. Tukey test for multiple comparisons was performed to test for a posteriori significant differences for mean variables at the significant level 0.05 .

Permutational multivariate analyses of variance (PERMANOVA, Anderson, 2001a) were used to examine spatial variation in assemblages in the 2 locations. The analyses were based on Bray-Curtis dissimilarities (Bray. Curtis, 1957) on untransformed data (5 assemblages at each location). Each term in analysis was tested, using 4999 random permutation of appropriate unites (Anderson, 2001b; Anderson and ter Braak, 2003). The analysis was carried out using the FORTRAN program PERMANOVA (Anderson, 2005). Analysis of variance was also used to estimate variance components at three spatial scales (between locations, among stations. and within replicates) and temporal variances at each location. Estimates were obtained by equating observed and expected mean squares for the specific model of analysis (Benedetti et al., 2003). Negative estimates were assumed to be sample underestimates of zero variance (Underwood, 1996; Fletcher and Underwood, 2002) but actual values are presented in tables. Graphical representations of multivariate patterns of nematode trophic assemblages were obtained by non metric multidimensional scaling (nMDS) at each location separately and at both locations combined. The MDS were based on Bray-Curtis dissimilarities.

The community structure of nematode trophic guilds was analyzed by using factor analysis (Principal component analysis, PCA). Three analyses were performed. Two analyses for data sets from EH and RE as well as one analysis for the overall data of EH and RE combined. Analyses of nMDS and PCA were applied by using SYSTAT program (1998).

\section{RESULTS}

Fig (2) shows the distribution of total nematode abundance at EH and RE. Due to wide range of variation in data log scale was used. Nematode abundance (individuals per $10 \mathrm{~cm}^{2}$ ) was higher at the $\mathrm{EH}$ than at RE. At the EH, nematode abundance ranged from $>10^{3}$ to $\geq 10^{5}$ individuals per $10 \mathrm{~cm}^{2}$ by an order of magnitude, whereas the abundance did not exceed $10^{2}$ individuals per $10 \mathrm{~cm}^{2}$ at RE (Fig.2 A\&B). Although there was no obvious difference in total nematode abundance at the $\mathrm{EH}$ over dates and amorg stations, St.1 had the highest abundance during April and November and its ranking shifted to the third and fourth in August and February respectively. The nematode abundance increased gradually from April to August at RE and st.1. 

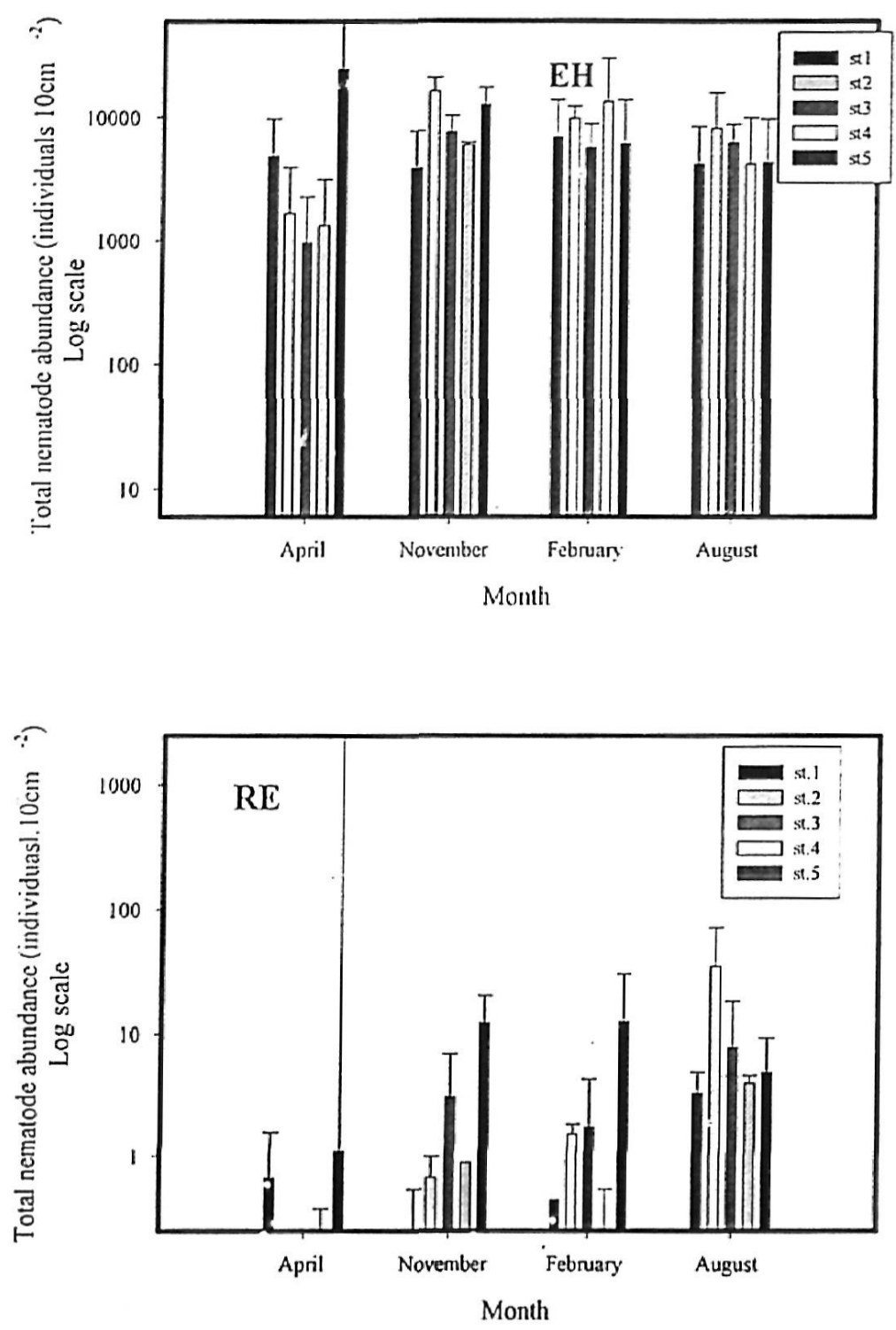

Fig.2. Temporal and Spatial distribution of total nematode abunadnce (individulas per $10 \mathrm{~cm}^{2}$ ) at the EH and RE ( $\log$ scale data was used).

Results from 3 way AN OVA revealed that the total nematode abundance and different trophic guilds were significantly different between $\mathrm{EH}$ and RE. Total nematode abundance and epistrate feeders were significantly different over dates $(\mathrm{p}<0.05)$ (Table 1). April had the posteriori significant nematode abundance (Tukey test). For epistrate feeders, the abundance was different in August from 
February as well as the abundances in August and February were different from those in April and November.

Table (1). Probabilities from three way ANOVA and its posterion Tukey tests based on $4^{\text {th }}$ squarc transformed replicated data of total nematodes abundance (individuals $10 \mathrm{~cm}^{-2}$ ) and its trophic guilds between Eastern Hr-bor (EH) and Rosetta esinary (RE). over datcs, among stations and their interactions. Abbreviations: $A p=A p r i l, A u=A u g u s t, F e b=$ February, Nov $=$ Novmber, $d f=$ degree of freedom, $p=$ probability at signilicint $\alpha$ level $=0.05$.

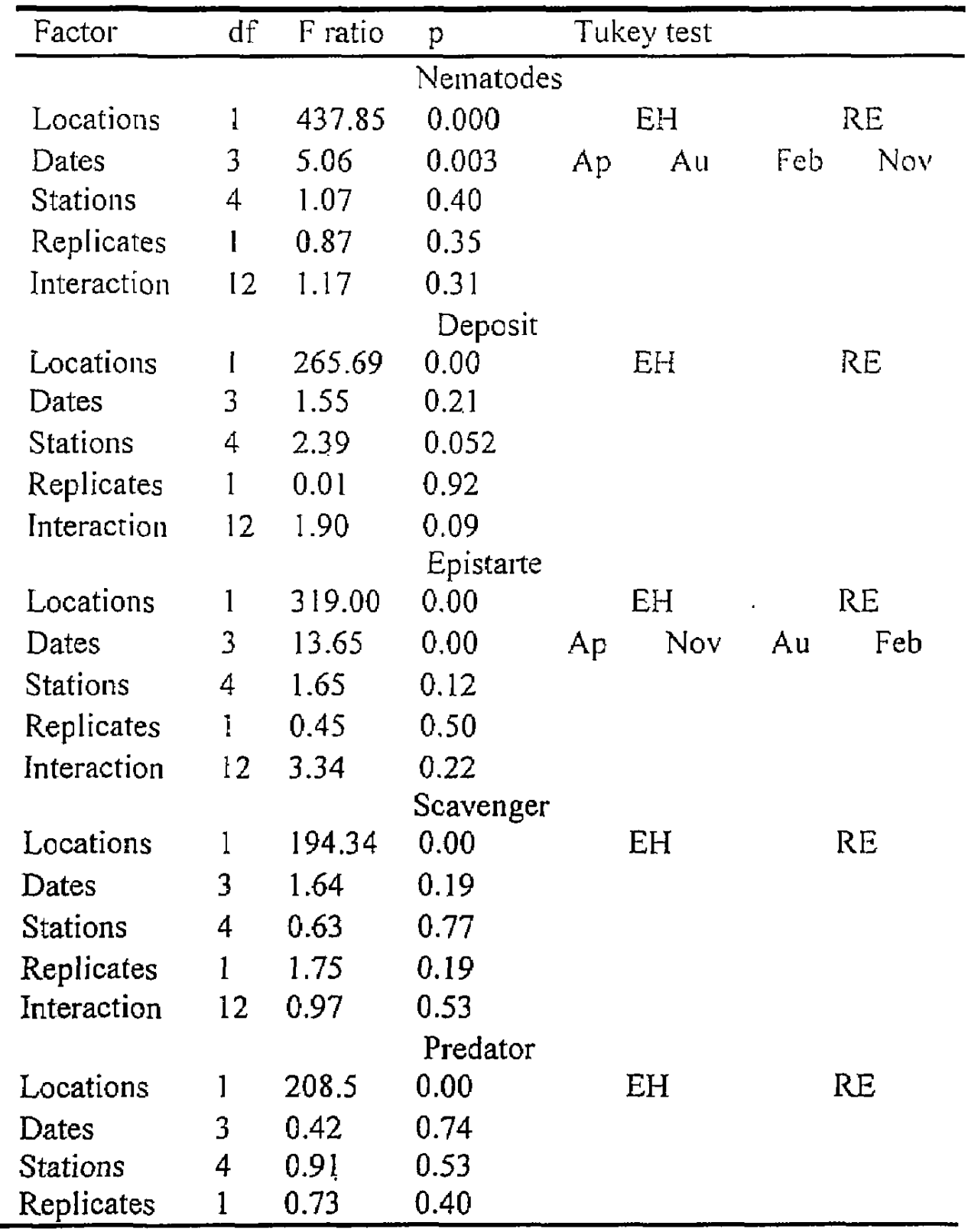


Trophic structure of nematode assemblages at EH and RE is reported in (Fig.3). Deposit feeders dominated at all stations and accounting for $37 \%$ and $46.5 \%$ respectively at $\mathrm{EH}$ and $\mathrm{RE}$ ). Epistrate feeders ranked secondly at both locations with higher relative importance at $\mathrm{RE}$ than at $\mathrm{EH}(38.5 \%$ and $35 \%$ respectively at $\mathrm{RE}$ and $\mathrm{EH}$ ). The relative importance of scavengers and predators was low at each location and their contributions were lower at RE than at EH (14\% and $16 \%$ for scavengers respectively at RE and $\mathrm{EH}$ as well as $1.5 \%$ and $11 \%$ for predators at $\mathrm{RE}$ and $\mathrm{EH}$ respectively).

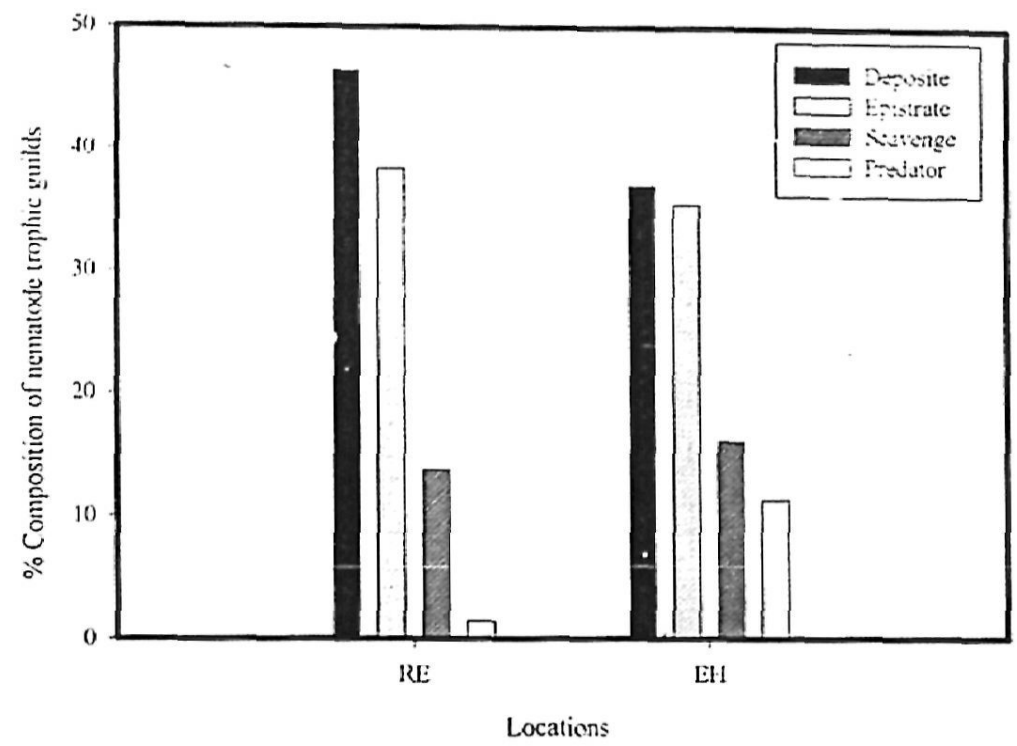

Fig.3. Percentage composition (\%) of different nematode guilds at the $\mathrm{EH}$ and RE.

Results from PCA (Fig.4) evaluated the relationship among different trophic groups. First of all, at the EH (Fig. 4 A), there was negative relationship between deposit feeders (loaded negative on PC1) with predators and scavengers (loaded positively on PC1). At the same time, Epistrate feeders loaded negatively with deposit feeders as well as with predators on PC2. The relationship between deposit and predators was positive on PC2. The relationship between epistrate feeders and scavengers was weak on both PCs. At The EH, the relationship among different trophic guilds has relatively the same magnitude and different signs. Secondly, at the RE (Fig.4B), the relationships among trophic guilds were completely different from that at EH. All trophic guilds loaded positively on $\mathrm{PC1}$. At PC2, epistarte feeders and predators correlated positively with each other and negatively with deposit and scavengers and vice versa. Thirdly, results from combined data sets of EH and RE (Fig.4C) 
revealed the positive loading of different groups on $\mathrm{PCl}$ and revealed positive correlation between deposit and epistarte feeders with each other and negative correlation with predators and scavengers on PC2. Predators and scavengers loaded positively on PC2.
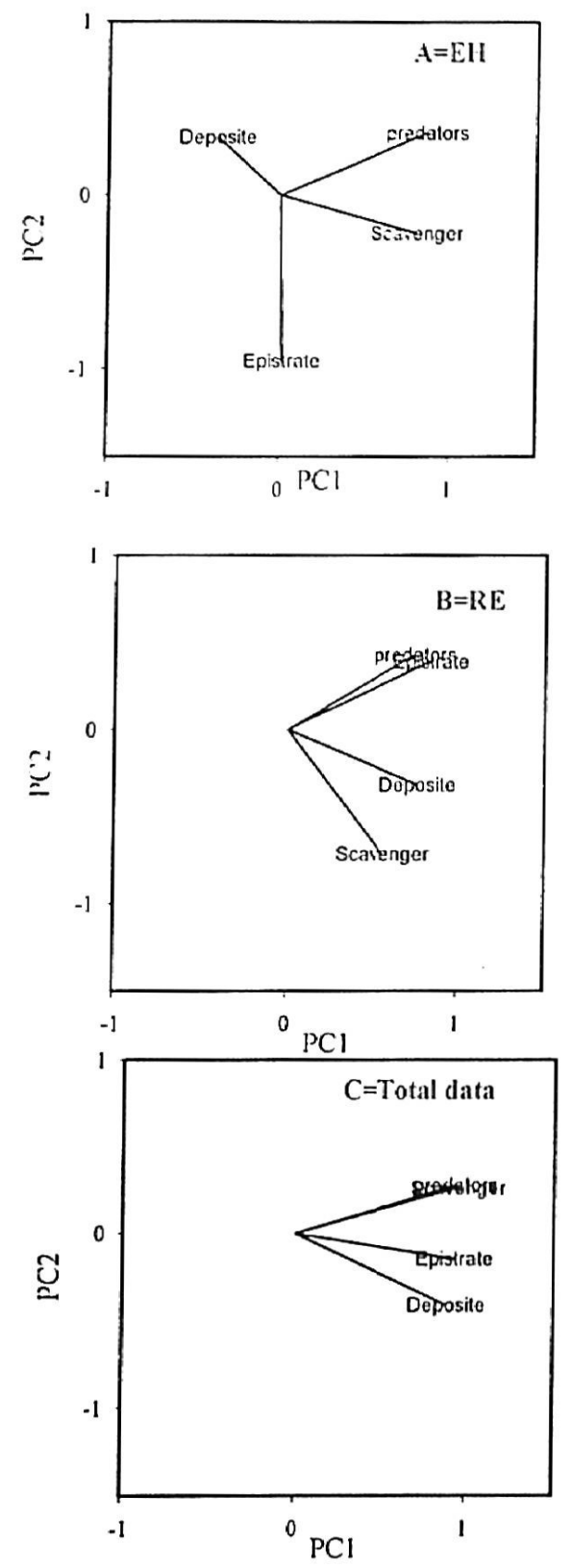

Fig.4. Factor analysis( $\mathrm{PCA})$ revealing the biological interactions among different trophic guilds at the $\mathrm{EH}(\mathrm{A}), \mathrm{RE}(\mathrm{B})$ and from the combined data of both locations (C).

Results from multivariate analysis; PERMANOVA (Tables 2, 3 and Fig.5) provided evidence that the structure of nematode assemblages differed significantly at the macro scales (locations) considered in this study. Results 
revealed the following points: there was significant variation in mean total data set, mean total nematode abundance and deposit feeders between $\mathrm{EH}$ and RE and over dates $(P<0.05)$. Significant variations in mean abundance of epistrate feeders were recorded over dates only. At the same time, mean abundance of scavengers was significantly different within stations whereas, predators did not show any significant variation at any level. Moreover, results from variance component (\% variance) were surprisingly. Estimates of multivariate variations decreased with decreasing spatial scale, the lowest variations occurring among replicates as indicated by residual mean square (Table 2). The variability at the macro-scale (locations) was much higher than at the meso-scale (stations) and micro scale (replicates/ residual). Moreover, most results revealed that variability within stations were negative results (Table 2) except for scavengers (74.3\%). Negative estimates from analysis of variance are automatically set to zero without consideration of the appropriateness of this procedure in terms of consequences for altering the remaining estimates (Fletcher and Underwood, 2002). There were large temporal variations within those locations as indicated by $\%$ of Variance (Table 2).

At $\mathrm{EH}$, pair wise comparison test after PERMANOVA (Table 3) revealed the highly significant differences in mean abundance of overall data set, total rematodes and deposit feeders. A posteriori significant differences in mean overalj data set and in mean data of epistrate feeders were detected in April. In addition, April had a posteriori different nematode abundance from August. At RE, mean overall data set was a posteriori significant in February from April and August and between April and August for the mean total nematode abundance. Concerning the variations of mean abundance of scavengers among stations at EH, st.1 and st.5 had posteriori significant variations from each other and from the rest of stations. At RE, st.4 had a posteriori significant variations.

Visual inspection of nMDS plot (Figs.5 A \& B) illustrates clearer differences among five stations at the EH from RE. In addition stations were widely scattered providing evidence of important variations at the scale of Kilometer. As for the whole data set (Fig. 5C) shows in more detail an exampie of spatial variability of the assemblages within one station (st.1), at the scale of stations. The nMDS plot clearly whole data set (Fig.5C) shows in more detail an example of spatial variability of the assemblages within one station (st. I), at the scale of stations. The nMDS plot clearly depicted the results obtained by PERMANOVA that st. 1 was well separated from other sites (Fig.5A, B, C). In addition the structure of assemblages of sts 2 and $3(\mathrm{EH})$ as well as sts 2 and 5 (RE) showed negligible separations. 

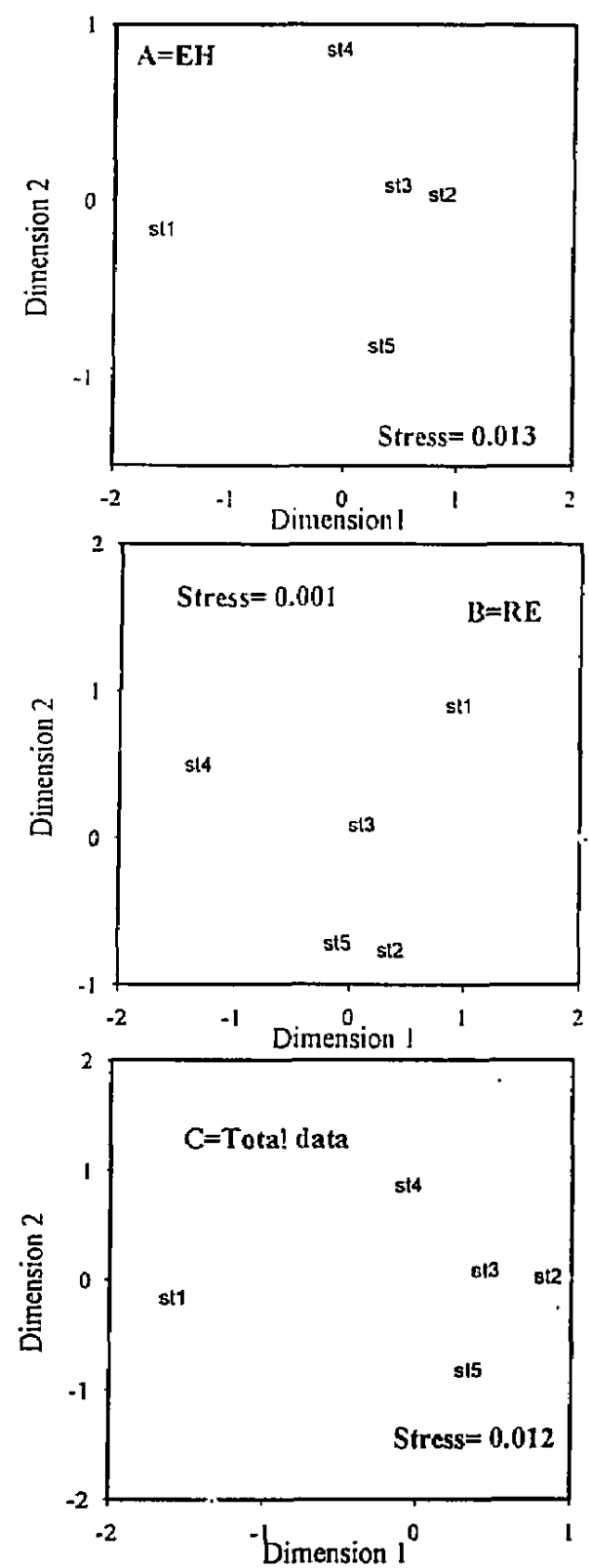

Fig.5. The non multidimeational scaling plot illustrates clearer differences among five stations at $E H(A)$ from those at $R E(B)$.

Fig.5C illustrates the separtaion of St. 1 from the rest of stations. 
Table (2): PERMANOVA based on Bray Curtis dissimilarities of the multivariate data set (overall data=nematodes, deposit, epistrate, scavenger and predator). Overall data, nematodes and epistart were untransformed. Deposit data were $4^{\text {th }}$ root transformed. Scavenger and predator data were standardized to Z-scores. Each term was tested using 4999 random permutation of appropriate units. Estimates of variance Component (V.C \%) are given for each spatial scale. Bold values indicate significant probability at $\alpha$ level $\leq 0.05$. Abbreviations: $S S=$ sum of squared distances, $M S=$ mean squared distances, $\mathrm{d} f=$ degree of freedom, $\mathrm{F}=\mathrm{f}$ ratio, $\mathrm{p}(\mathrm{perm})=$ permutation probabilit: loc=location, dat $=$ date, st $=$ station and locdat $=$ location $\times$ date

\begin{tabular}{|c|c|c|c|c|c|c|}
\hline Source & $\mathrm{d} \Gamma$ & SS & MS & $F$ & $P($ perm $)$ & $\%$ Variance \\
\hline \multicolumn{7}{|c|}{ Tolal dala sel (Tive items) } \\
\hline loc & 1 & 92164.82 & 92164.82 & 15.63 & 0.0002 & $73 \%$ \\
\hline $\operatorname{dat}(\operatorname{loc})$ & 6 & 35374.31 & 8595.72 & 2.69 & 0.004 & $33 \%$ \\
\hline sl (liodal) & 32 & 70035.32 & 2188.60 & 0.89 & 0.7624 & $-1.17 \%$ \\
\hline residual & 40 & 98274.00 & 2456.84 & & & \\
\hline tolal & 79 & 295848.41 & & & & \\
\hline \multicolumn{7}{|c|}{ Nemalodes } \\
\hline loc & 1 & 90913.83 & 90913.83 & 15.35 & 0.0002 & 75.49 \\
\hline dat $(b c)$ & 6 & 35526.51 & 5921.08 & 2.66 & 0.0006 & 4.11 \\
\hline st (wodat) & 32 & 71131.59 & 2222.86 & 0.87 & 0.8028 & -1.42 \\
\hline residual & 40 & 101666.36 & 2541.66 & & & \\
\hline \multirow{2}{*}{\multicolumn{7}{|c|}{ Deposit }} \\
\hline & & & & & & \\
\hline loc & 1 & 34562.55 & 34562.55 & 13.78 & 0.0036 & 54.83 \\
\hline dat(loc) & 6 & 15045.82 & 2507.64 & 2.43 & 0.0256 & 3.16 \\
\hline st (locdat) & 32 & 32969.82 & 1030.31 & 0.999 & 0.491 & -0.006 \\
\hline residual & 40 & 41240.11 & 1031.00 & & & \\
\hline total & 79 & {$[23818.30$} & & & & \\
\hline \multicolumn{7}{|c|}{ Epistarte } \\
\hline 100 & 1 & 13615.228 & 13615.2270 & 1.265 & 0.299 & 7.1 \\
\hline $\operatorname{dat}(10 \mathrm{c})$ & 6 & 64578.11 & 10763.0191 & 52.31 & 0.0002 & 32.8 \\
\hline st (locdat) & 32 & 6584.76 & 205.7739 & 0.71 & 0.8694 & -1.11 \\
\hline residual & 40 & 11606.67 & 290.1666 & & & \\
\hline total & 79 & 96384.77 & & & & \\
\hline \multicolumn{7}{|c|}{ Scavenger } \\
\hline loc & & 1720451.51 & 1720451.51 & -1.41 & 0.94 & 90.99 \\
\hline $\operatorname{dat}(\mid O c)$ & 6 & -7327830.4 & -1221305.1 & -2.50 & 0.999 & -66.04 \\
\hline st (locdat) & 32 & 15618918.9 & 488091.215 & 65.95 & 0.0002 & 0.0002 \\
\hline residua! & 40 & 296001.3 & 7400.0325 & & & \\
\hline \multirow{2}{*}{\multicolumn{7}{|c|}{ Predator }} \\
\hline & & & & & & \\
\hline loc & 1 & 5292873.97 & 5292873.97 & -4.6257 & 0.8724 & -578.07 \\
\hline $\operatorname{dat}(\operatorname{loc})$ & 6 & -6865332 & -1144222 & 2.02 & 0.2634 & 65.17 \\
\hline st (locdat) & 32 & -18050049 & -564064.02 & -0.6999 & 0.7718 & 615.15 \\
\hline residua] & 40 & 32237555.5 & 805938.889 & & & \\
\hline tola] & 79 & 12615048.8 & & & & \\
\hline
\end{tabular}


Table (3). Comparison tests after PERMANOVA analyses between two locations Eastern Harbor $(E H)$ and Rosetta Estuary (RE), among four dates April (Apr), November (Nov). February (Feb), August (Aug), and within five stations (St). Abbreviations: $t=T$ test, $p=$ Probability at different significant levels $\left(*=0.05,{ }^{* *}=0.001, * * 0.0001\right) . n s=$ not significallt, $V_{s}=$ against

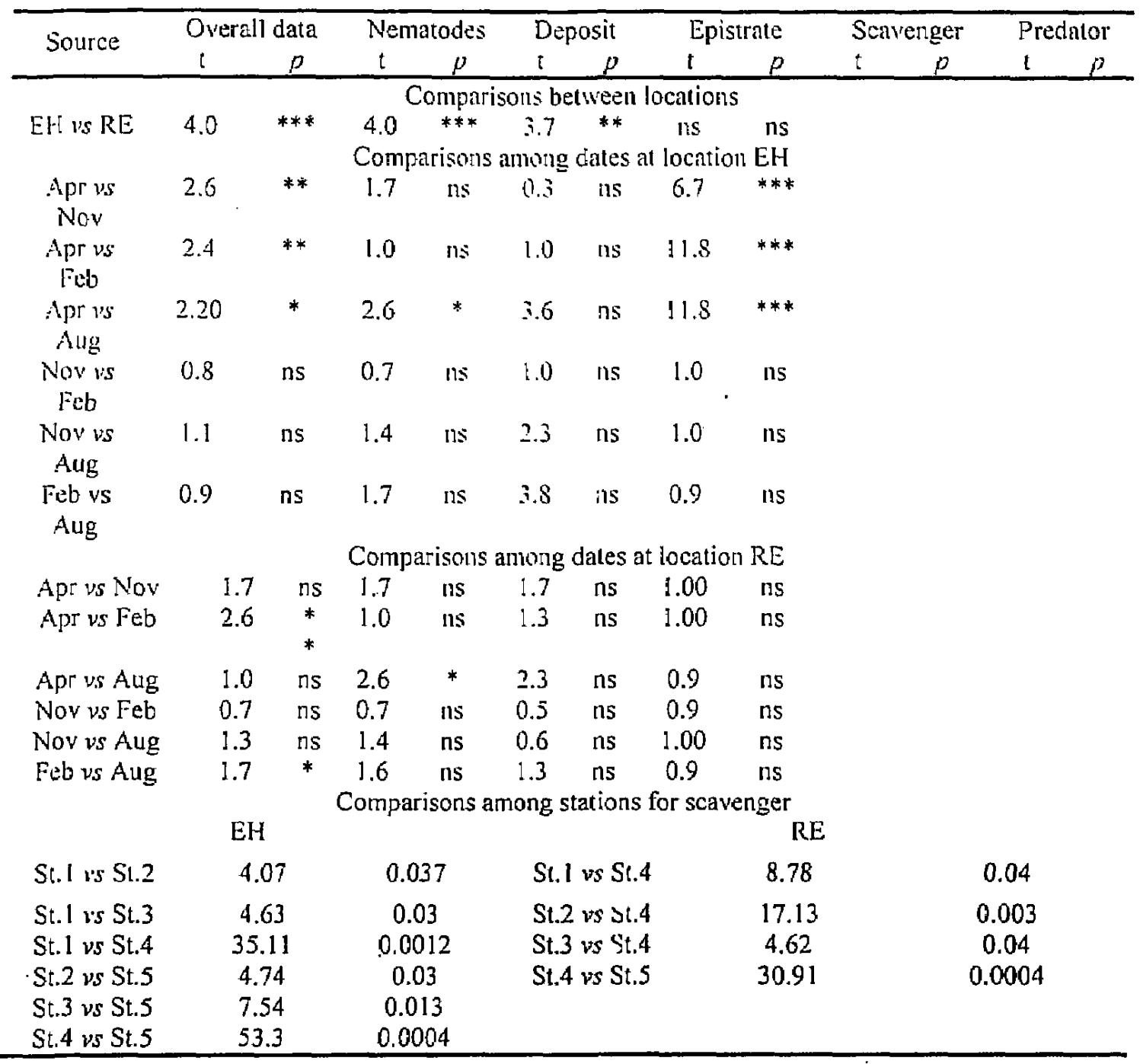

\section{DISCUSSION}

The higher nemat: de abundance at the EH than RE could be related to different reasons such as availability of food sources, mean grain size and sediment composition, as well as to hydrodynamic processes that governed the areas, or more even due to some environmental factors (temperature, salinity in addition to pollution factors). Both the $\mathrm{EH}$ and RE had high percentage of total organic carbon (Mitwally et al. 2007; 2007a; Bader El Din, 2007; Mitwally and Awads, 2005; Jammo, 2004) and the \% of OM was higher at RE due to River 
Nile supplies (EI Shanwany, 2004). In addition, the fine grain sand predominated the RE, whereas the sediment at the $\mathrm{EH}$ ranged from coarse sand to fine silt (El Shanwany, 2004; Mitwally et al., 2007a; EL Doughiem, 2005; Bader El Dine, 2007). High nutrient loadings could be responsible for the reduction of diversity through several mechanisms which include acceleration and destabilization of inter-specific interactions and the alternations of nature and scale of habitat heterogeneity (Rex, 1983; Etter and Grassie, 1992; Rex et al, 1993). This gives explanation that food availability is not limiting factor in RE sediments and other factors are likely to be responsible for reduction of nematode abundance at $R E$.

The $\mathrm{EH}$ is semiclosed basin, which is sheltered from the sea by an artificial breakwater (Fig.lA). In general, extremely high abundances of meiofauna with nematodes always the dominant taxon are characteristic of sheltered muddy regions of estuaries (Heip et al., 1985). Mitwally and Awads (2005) found that $\mathrm{EH}$ is rich in meiofaunal abundance and diversity of taxa due to the availability of food sources (organic carbon, chlorophyll contents and Bacteria). Mitwally (2007) attributed the high nematode abundances at some stations to the coarseness of sediments and high organic load that afford a suitable environment to nematode to consume the organic matter. Organic matter is the basic energy source for the meiofaunal food web and could be responsible for increasing meiofaunal abundance (Grebmeier et al., 1989; Danovaro et al., 1996). The highest meiofaunal abundances wese associated with high organic matter sediments and meiofauna results correlated positively with organic matter at the EH (Soetaert et al., 1997; Shabaka 2004; Mitwally and Awad, 2005; Mitwally et al., 2005; Mitwally et al., 2007). The EH has heterogeneous substrates (El- Doghieum, 2005; Badr el din, 2007). According to Tietjen (1984) more heterogeneous substrates are responsible for a higher number of microhabitats and this might result in an increase of species abundance, richness and to lesser extent evenness. A combination of very fine sand and percentage of shell fragments provided the best suit of variables to determine the different nematode assemblages (Gheskiere et al., 2004). The sedimentological parameters are the main factors controlling the distribution of meiofaunal abundance (Ansari and Parulekar, 1994; Schratzberger et al., 2000; Jammo, 2004). Sediment composition and availability of food sources are the main factors controlling nematode abundance at the $\mathrm{EH}$.

On the other hand, RE is highly dynamic ecosystem that suffered from continuous erosion and accretion which in turn leads to instability of sea bed (Abo Zed and Shereet, 2005). Bed instability is playing a dominant role in controlling meiofauna (Gray and Riger, 1971). The erosion, transport and redeposition of sediments are major sources of physical disturbance for soft sediment habitats and associated communities. Those events cause perturbation which affects the benthos (Aller, 1989). El Shanawany (2004) stated that high erosion or accretion rate is accompanied by low meiofaunal abundances. 
Mitwally et al (2007a) concluded that hydrodynamic processes (erosion and accretion rates) reduced the number of recorded taxa and total abundance of each metazoan taxon. Hydrodynamic processes (erosion and accretion) are the limiting factors in RE.

The quantity and variety of organic matter allow co-existence of different feeding types (Jensen, 1987; Moens and Vincx, 1997). In the present study, deposit feeders dominated the nematode assemblages at RE and EH with higher contribution at RE. Their relevance is also consistent with the presence of large amounts of fresh organic detritus. especially at RE due to River Nile supplies. The current findings agreed with Gambi et al. (2003). Epistarte feeders (nematodes are feeding on diatoms and microalgae) ranked to the second order, with no big differences in their relative importance between epistrate and deposit feeders (Fig.3). This probably related to the prevalence of fine grain sand at the RE and availability of food sources at EH. Mitwally (1999) found that predominance of homogenous finer sand lead to dominance of deposit feeders followed by epistrate feeders. Mitwally and Awads (2005) recorded strong correlations between meiofaunal abundance and chlorophyll.

Scavengers and predators accounted for minor fraction of total nematode assemblages (Fig.3) suggested that the negligible contribution of this feeding type could indicate the absence of freshly dead organisms on one side (Tietjen, 1969; Gambit et al., 2003). On the other side. the minor contribution of predators at both locations and especially at RE probably were related to the high organic load and prevalence of finer grain sand. Pello et al. (1998) recorded predators /omnivores to have higher abundance in sediment with low organic matter. Mitwally (1999) recorded predators as the dominant group in the most coarseness beach in her study. Since the predators are generally characterized by large size (Gambi et al, 2003), the low abundance of this group might also related to the prevalence of finer grain sand $\mathrm{RE}$ and $\mathrm{EH}$. At the EH, spots of coarse grain sediment hosted higher proportion of predators than at RE. The mean nematode size was strongly correlated with the median grain sizc i.e. increase of the particle size diameter resulted in increase in nematode size (Udalov et al. 2005). Results from PCA (fig.4a) confirmed the heterogeneity of sediment at the $\mathrm{EH}$ where the relative importance of different trophic groups has relatively the same magnitude and different signs. However, the different signs among trophic level (Fig.4) indicated the biological interaction such as competition and predation among different guilds. In most a tidal beaches, including the Egyptian Mediterranean coast, biological interactions such as competition and predations were thought to control meiofaunal abundance (Peres, 1967; Hulings and Gray, 1976). On the contrary, at RE, the positive loading of different trophic guilds at $\mathrm{PCl}$ was related to the homogenous sand (Fig.4B) or the prevalence of finer grain sand (Fig.4C). This homogenous sand minimized the relative importance of scavengers and predators but did not prevent the biological competition of predators and epistrat feeders on one side 
and deposit feeders and scavengers on the other side. (negative loading on PC2). The more the heterogeneous sediment, the higher the relative importance of different trophic guilds was reported and vice versa.

The surprising results were the higher spatial variation on larger scale (table 2) rather on smaller scale. Many studies revealed that variation on the smaller scale is always much higher than on larger scale (Cecchi, 2001; Benedetti-Cecchi et al., 2003; Fraschetti et al., 2005; 2006; Terrlizi et al., 2005a; 2005b; Benedetti- Pardi el al., 2006; Tuya \& Haroun, 2006; Johnson et al., 2007; Mitwally and Abada, 2008). However, the current results agree with those of Li et al. (1997)and Steyaert et al. (2003) indicating that physical factors may be more important in generating macro-scale (e.g. km scale) heterogeneity than micro-scale heterogeneity. In addition, on larger scale, sediment characteristics seem to determine the gross assemblages structure (Ndaro and Olafsson, 1999). The significant variation on the larger scale (between EH and RE) could be due to widespread geographical distribution of physico-chemical and sedimentological variables as well as hydrodynamic processes.

\section{CONCLUSIONS}

The nematode abundance was higher at the sheltered semi-closed (EH) basin than at the highly dynamic area (RE). The higher abundance at EH is probably related to the availability of food sources (organic matter, chlorophyll and bacteria) and the heterogeneous sediment. At RE the hydrodynamic process in addition to prevalence of finer grain sand (homogenous sand) were the limiting factors for nematode abundance. Nematode trophic guilds consisted of four groups (deposit feeders, epistrate feeders, scavengers and predators, according to Jensen's classification) at both locations and dominated by deposit feeders due to high load of organic matter. However, the relative importance of different trophic guilds was equal in magnitude and different in signs at $\mathrm{EH}$, indicating the heterogeneous sediment and the biological competition among groups. At RE, the higher relative importance of deposit and epistrate feeders than scavengers and predators revealed again the dominance of finer grain sand and high organic matter. The finer the grain sand and the higher the organic content, the lower the scavengers and predators was. The higher the spatial variability on large scale was due to physical, hydrodynamic factors as well as sediment characteristics.

\section{ACKNOWLEDGMENTS}

The author is indebted to Ms Rehab El Shanawany (Alexandria University, Environmental Sciences Department) for her help in collecting samples from Rosetta estuary. 


\section{REFERENCES}

Aboul Kassim, T.A.T. (1987). Cycles of Carbon, Nitrogen and phosphorus in the marine environment in Alexandria region. M. Sc. thesis, Faculty of Science, Alexandria, University, 233pp.

Abo-Zed, A.I and Shereet, S.M. (2005). Dynamics of near shore sediments and coastal changes Astride Rosetta Branch, Egypt. Emirates Journal for Engineering Research, 10(2):51-61.

Ahmed, M.F. (2002). Multi -temporal conflict of the Nile Delta coastal changes, Egypt. Littoral, The changing Coast. EUROCOASt / EUCC: Porto-Portugal Ed. Eurocoast-Portugal, ISBEN 972-8558-09-0.

Aller, J.Y. (1989). Quantifying sediment disturbance by bottom currents and its effect on benthic communities in a deep sea western boundary zone. Deep Sea Research, 36(6):901-934.

Anderson, M.J. (2001a). A new method for non -parametric multivariate analysis of variation. Austral Ecology, 26:32-46.

Anderson, M.J. (2001b). Permutation tests for univariate or multivariate analysis of variance and regression. Candian Journal of Fisheries and Aquatic Sciences, 58:626-639.

Anderson, M.J. (2005). PERMANOVA. Permutational multivariate analysis of variance. A computer program. Department of Statistics, University of Auckland, 23pp.

Anderson, M.J., and ter Braak, C.J.F. (2003). Permutation tests of multifactorial analysis of variance. Journal of statistical computation and simulation, 73:301-318.

Ansari, Z. A. and Parr'eker, A. H. (1994). Meiobenthos in the sediment of seagrasses meadows of Lakshadweep atolls, Arabian Sea VIE MILIEU, 44(3/4): 185-190.

Bader El Din, A.M. El. 2007. Study of pollution effect on the benthic communities (meiofauna and foraminifera) in recent marine 
sediments of Alexandria, Egypt. Ph.D. thesis, Faculty of Science, Alexandria, University, 156pp.

Benedetti-Cecchi, L. (2001). Variability in abundance of algae and invertebrates at different spatial scales on rocky sea shores. Marine Ecology Progress Series, 215: 79-92.

Benedetti-Cecchi, L.; Maggi E.; Bertocci I.; Vaselli S.; Micheli F.; Osio G.C. and Cinelli F., (2003). Variation in rocky shore assemblages in the northwestern Mediterranean: Contrasts between islands and mainland. Journal of Experimental Marine Biology and Ecology, 293:193-215.

Bray, J.R. and Curtis J.T., (1957). An ordination of the upland forest communities of southem Wisconsin. Ecological Monographs, $27: 325-349$

Danovaro, R.; Fabiano, M.; Albertelli, G. and Della Croce N. (1996). Vertical distribution of meiobenthos in bathyal sediments of the Eastern Mediterranean sea:relationship with labile organic matter and bacterial biomasses. Marine Ecology. PSZNI, 16: 103-116.

El-Dughiem, M. I. (2005). Geochemistry of some trace elements in the bottom sediments of the Eastern Harbor of Alexandria, Egypt". Ph. D. Thesis. Faculty of Science, Alexandria, University 219 pp.

El Nady, F. E., (1981). Survey of some heavy metals in Alexandria water and its effect on some marine animals. Ph. D. Thesis, Faculty of Science, Alexandria, University, 317pp.

El Sayed, M. A. and El Sayed, M. K., (1980). levels of heavy metals in the surface waters of a semi enclosed basin along the Egyptian Mediterrar:zan coast. Workshop on pollution of Mediterranean ICEM. Cagaliari,9-130ct.1980; pp223-228.

EL Shanawany, R.A. (2004). Effect of coastal hydrodynamic processes on benthic meiofauna community off Rosetta promontory, 
Egypt. M. Sc. thesis, Faculty of Science, Alexandria, University, 135pp.

Etter, R. J. and Grassle, J.F. (1992). Patterns of species diversity in the deep sea as function of sediment particle size diversity. Nature 360:576-578.

Fanos, A.M.; Khafagy: A. A. and Dean, R. G. (1995). Protective works on the Nile Delta Coast. Journal of Coastal Research, 11:516528.

Fletcher, D. J, and Underwood, A. J. (2002). How to cope with negative estimates of components of variance in ecological field studies. Journal of Experimental Biology and Ecology, 273:89-95.

Fraschetti, S.; Teriizzi A and Benedetti-Cecchi, L. (2005). Patterns of distribution of marine assemblages from rocky shores: evidence of relevant scales of variation. Marine Ecology Progress Series, 296: 13-29.

Fraschetti, S.; Gambi, C.; Giangrande, A.; Musco, L.; Terlizzi, A. and Danovaro, R. (2006). Structural and functional response of meiofauna rocky assemblages to sewage pollution. Marine Pollution Bulletin, 52: 540-548.

Frihy O. E.; Fanos, A. M.; Khafagy, A. A. and Komar P. D. (1991). Nearshore sediment transport patterns along the Nile Delta Egypt. Journal of Coastal Engineering, 15:409-429

Gambi, C.; Vanrreusel, A. and Danovaro, R. (2003). Biodiversity of nematdoe assemblages from deep sea sediments of the Atcama slofe and trench (South Pacific Ocean). Deep Sea Research I, 50:103-117.

Gheskiere,T.; Hoste, E.; Vanverberke, J.; Vincx, M. and Degraer, S. (2004). Horizontal zonation patterens and feeding structure of marine nematode assemblages on a mactotidal, ultra-dissipative sandy beach DePanne, Belgium. Journal of Sea Research, $52: 211-226$. 
Gerlach, S. A. M. (1963). Freilebende Meeresnematoden von den Malediven II. Kieler Meeresforschungen, 19:67-103.

Gerlach, S. A. M. (1964). Freilebende Nematoden aus dem troten Meer. In: Remane, A and Schultz (eds), Wissenschaftliche ergebnissr einer forschungsreise von nach dem Rotten Meer. Kieler Meeresforschungen, $169 \mathrm{pp}$.

Gray, J.S. and Rieger, R.M. (1971). A quantitative study of the meiofauna of an exposed sandy beach, at Robin Hood's Bay, Yorkshire. Journal of the Marine Biological Associations of the United Kingdom, 52:1-18.

Grebmeier, J. M.; Feder, H. M. and McRoy. C. P. (1989). Pelagic-benthic coupling on the shelf of the northern Bering and Chukchi Seas. II. Benthic community structur?. Marine Ecology. Progress Series, 51: 253-268.

Heip, C.; Vincx, M. and Vranken, G. (1985). The ecology of marine nematodes. Oceanography and marine Biology Annual Review, 23:399-489.

Hulings, N. C. and Gray, J. (1976). Physical factors controlling abundance of meiofauna on tidal and atidal beaches. Marine Biology, 34:77-83.

Huys, R.; Gee, M. ; Moore, C. G. and Hamond, R. (1998). Marine and brackish water harpacticoid copepods. Part 1, In: Synopses of the British fauna (new series). Barnes, R.S.K. \& J.H. Crothers (eds). Linnean Soc. Estuarine Coastal Sci. Assocc. Publ. 51pp.

Inman, D.L.; Aburey, D. G. and Pawka, S. S. (1976). Application of near shore processes to the Nile Delta. In UNESCO/UNDP proceedings Seminar Nile Delta sedimentology, Alexandria, pp. $205-255$.

Inman, D.L. and Jenkins S. A., (1984). The Nile littoral cell and man's impact on the coastal zone of the southern Mediterranean. Scripps institution of Oceanography, series 84-31, University of California, La Jolla,43pp. 
Jammo, K.M. (2004). "Biodegradation of organic matter in marine environment of Alexandria (Eastern Harbor)". PhD. thesis, Fac. Sci, Alex. Univ., 304pp.

Jensen, P. (1986). Nematode fauna in sulphide rich brine seep and adjacent bottoms of the East Flower Garden, NW Gulf of Mexico. IV. Ecological aspects. Marine Biology, 92:489-503.

Jensen, P. (1987). Feeding ecology of free living aquatic nematodes. Marine ecology progress series, 35:187-195.

Johnson, D. S; Fleeger, J.W. and Gaivan, K.A. (2007). Worm holes and their space -time continuum: Spatial and temporal variability of macroinfaunal annelids in a northern New England Salt March. Variability of salt marsh macroinfauna. Estuaries and Coasts, 30(2):226-237.

Lampadariou, N. and Tselepides, A. (2006). Spatial variability of meiofaunal commuinities at areas of contrasting depth and jiroductivity in the Aegean sea (NE Mediterranean). Progress in Oceanography, 69:19-36.

Li, J.; Vincx, M.; Herman, P. M J. and Heip, C. (1997). Monitoring meiobenthos using $\mathrm{cm}-, \mathrm{m}$ - and $\mathrm{km}$-scales in the southern Bight of the North Sea. Marine Environmental Research, 43 (4): 265 278.

McIntyre, A. D. (1969). Ecology of Marine Meiobenthos. Biological Review, 44:245-290.

Micoletzky, H. (1924). Weitere Beituge zur Kenntnis Freilebende Nematoden aus Suez. S-B. Akad. Wiss. Wien, I (132):225-262.

Micoletzky, H. (1924a). Letzter Bericht hber Freilebende Nematoden aus Suez. S-B. Akad. Wiss. Wien, I (133):137-179.

Mitwally, H. M. (2007). Using the nematode to harpacticoid copepod ratio as a monitoring tool of benthic organic pollution. Egyptian Journal of Aquatic Research, 33(3):88-102. 
Mitwally, H. M. (1999). Ecological and systematic studies of the interstitial fauna and benthic diatoms in the sandy beaches of Alexandria". Ph.D. Thesis, Faculty of. Science., Alexandria. University, $324 \mathrm{pp}$.

Mitwally, H.M. and Abada, A.A. (2008). Spatial variability of meiofauna and macrofauna in A Mediterranean protected area, Burullus lake, Egypt. Meiofauna marina, 16:185:200

Mitwally H.M. and Awads, H.B. (2005). Distribution of Meiofauna in relation to abiotic and biotic factors in a semi-closed Harbor in Alexandria Egypt. Meiofauna. Marina, 14: 139-143.

Mitwally, H. M.; Khader, A.; Badr ElDin, A. M.; Samir, A.M.; ElSayed M. Kh. and El Sabarouti M. (2007). Is the benthic assemblages of meiofauna affected by heavy metals pollution? Proceeding of the eighth international conference on the Mediterranean coastal environment. MEDCOAST 07, (E. Özhan editor), 13-17 November 2007, Alexandria Egypt,pp.571-583.

Mirwally, H. M.; El Shanawany, R.A.; Ibrahim, M. I. A. and Frihy, O.E. (2007a). Spatial and temporal distribution of benthic meiofauna from two coastal stretches of Rosetta promontory, Egypt. Egyptian Journal of Experimental Biology (Zool), 3:113-126.

Mitwally, H.M.; Shabaka S.H.; Mostafa H.M. and Halim,Y. (2005). Distribution of meiofauna inside and outside Cymodocea nodosa meadow in Alexandria, Egypt. Meiofauna Marina, 14:145-156.

Mitwally, H.M.; Montagna P.A.; Halim Y.; Khalil A.N.; Dorgham M.M. and Atta M.M. (2004). Egyptian sandy beach meiofauna and benthic diatoms. Rapp. Comm. Int mEr Medit., 37:537.

Moens, T. and Vincx, M. (1997). Observations on the feeding ecology of estuarine nematodes. Journal of marine Biological Associations U.K.., 77:211-227.

.Ndaro, S. G. M. and Olafsson, E. (1999). Soft- bottom fauna with emphasis on nematode assemblage structure in a tropical 
intertidal lagoon in Zanzibar, Eastern Africa: I. Spatial variability. Hydrobiologia, 405:133-148.

Pardi G.; Piazzi, L.; Balata, D. ; Papi, I. ; Cinelli F and Benedetti-Cecchi L. (2006). Spatial variability of Posidonia oceanica (L.) Delile epiphytes around the mainland and the islands of Sicily (Mediterranean Sea). Marine Ecology, 27: 394-403.

Pèrès, J.M. (1967). The Mediterranean benthos. Oceanography Marine Annual review, 5:449-533.

Platt, H. M. and Warwick, R.M. (1983). A synopsis of the free living marine nematodes. Part I: British Enoplide. Cambridge University press, Cambridge, 307pp.

Quelennec, R. E. and Manohar M. (1977). Numerical wave refractions and computer estimation of littoral drift, application to the Nile Delta coast. In: Proceedings UNESCO seminal on Nile Delta Coastal processes, Alexandria, pp. 404-433.

Rex, M.A. (1983). Geographical patterns of species diversity in the deep sea benthos. In: Rowe, G.T. (ed) the sea. Wiley, New York, $8: 453-472$.

Rex, M.A.; Stuart, C.T.; Hessler, R.R.; Allen, J.A.; Sanders, H.L. and Wilson, G.D.F. (1993). Global scale latitudinal patterns of species diversity in the deep sea benthos. Nature, 365:636-639.

Schratzberger, M.; Gee, J.M.; Rees, H.L.; Boyd, S.E. and Wall, C.M. (2000). "The structure and taxonomic composition of sublittoral meiofauna assemblages as an indicator of the status of marine environments". J. Mar. Biol. Ass. UK., 801: 969-980.

Schratzberger, M.; Warr, K. and Rogers, S.I. (2007). Functional diversity of nematode communities in southwestern North Sea. Marine Environmental Research, 63:368-389.

Shabaka, S. (2004). "Ecological study of the benthic marine phanerogams meadows off Alexandria coast, Egypt". M. Sc. Thesis, Faculty of. Science, Alex. University., 210pp. 
Soetaert, K.; Vanaverbeke, J.; Heip, C.; Herman, P.M.J.; Middelburg, J.J.; Sandee, A. and Duineveld, G. (1997). Nematode distribution in ocean margin sediments of the Goban Spur (northeast Atlantic) in relation to sediment geochemistry. Deep sea research, 44 (910):1671-1683.

SYSTAT, (1998). Statistics version, $8^{\text {th }}$ edition. SYSTAT, Inc., SPSS.

Steyaert, M.; Vanaverbeke, J. ; Vanreusel, A. ; Baranguet, C.; Lucas, C. and Vincx, M. (2003). The importance of fine scale, vertical profiles in characterizing nematodes community structure. Estuarine, Coastal and shelf Sciences, 58:353-366.

Terlizzi, A.; Benedetti-Cecchi, L.; Bevilacqua, S.; Fraschetti, S.; Guidetti, P. and Anderson, M. J. (2005a). Multivariate and univariate asymmetrical analyses in environmental impact assessment: a case study of Mediterranean subtidal sessile assemblages. Marine Ecology progress Series, 289: 27-42.

Terlizzi, A.; Scuderi., D.; Fraschetti, S. and Anderson, M.J. (2005b). Quantifying effects of pollution on biodiversity. A case study of highly diverse molluscan assemblages in the Mediterranean. Marine Biology 148:293-305.

Tietjen, J. H. (1969). The ecology of shallow water meiofauna in two new England estuaries. Oecologia, 2:251-268.

Tietjen, J. H. (1984). Distribution and species diversity of the deep sea nematodes in Venezuela basin. Deep Sea Research I, 31:119132.

Tuya, F. and Haroun, R. J. (2006). Spatial patterns and response to wave exposure of shallow water algal assemblages across the Canarian Archipelago: a multi-scale approach. Marine Ecology Progress Series, 311:15-28.

Underwood, A. J. (1996). Spatial patterns of variance in density of intertidal populations. In: Floyd, B.B Shepard, A.W., De Barro, P.J. (eds), Frontiers of population ecology. CSIRO publishing, Melbourne, Australia, pp. 369-389. 
UNESCO/UNDEP, (1978). Coastal protection studies. Final Technical Report, Paris, 155pp.

Udalov, A.A.; Azovsky, A.I. and Mokievsky, V.O. (2005). Depth related pattern in nematode size: what does depth itself mean? Progress in Oceanography, pp. 67:1-23.

Zaghloul, F. A.(1988). Some physico-chemical indices of eutrophication in the Eastern Harbor of Alexandria. Bulletin National Institute of Oceanography and Fisheries. 14(2):39-53.

Zaghloul, F. A. and Halim, Y. (1992). Phytoplankton flora and its dynamics in the Eastern Harbor of Alexandria. Science of total environment, supplement, Elsevier Science Publisher B.V. Amsterdam, pp.727-735.

Wieser, W. (1953). Die Beziehung Zwischen Mundhehlenge-Salt, Ernehrungsweise und Vorkommen bei Freilebendden marinen Nematoden. Ark .Zool., 4:439-484.

Wieser, W. :(1959). The effect of grain size on the distribution of small invertebrates inhabiting the beaches of Pugetsound. Limnological Oceanography, 4:184-194.

Wieser, W. (1960). Benthic studies in Buzzards bay. II. The meiofauna. Limnological Oceanography,5:121-137.

Wieser, W. and Kanwisher, J. (1961). Ecological and physiological studies on marine nematodes from a saltmarsh near woods Hole, Massachusetts. Limnological Oceanography, 6:262-270. 